\title{
Conflicting Paradigms of Religious and Bureaucratic Authority in a British Mosque
}

\author{
Amin El-Yousfi \\ University of Cambridge, Cambridge CB2 1TN, UK; ae375@cam.ac.uk
}

Received: 16 May 2019; Accepted: 20 September 2019; Published: 30 September 2019

\begin{abstract}
This article analyses an on-going conflict between two groups (Bargil and Kardal) over the management of a mosque located in an area near London. Based on fourteen months of intensive fieldwork, including participant observation, informal chats and semi-structured interviews, this article offers an in-depth and original account of the transformations taking place in mosques concerning the role of imams and mosque committee members. By analysing the object of conflict, the organisational structure, the dynamic of the groups and its leaders, as well as the process of bureaucratisation of mosques as a material condition, I intend to scrutinise the role and status of the imam and mosque committee members. The primary aim of this article is to re-examine and challenge the narrative of decline in religious authority (in Western mosques) propounded by some scholars as being the result of individualisation and the rise of new religious figures outside traditional institutions. I suggest that rather than experiencing a decline in imams' religious authority, mosques have become controlled by the bureaucratic authority of the committee members. In other words, imams' religious authority is still exercised, yet only within the bureaucratic framework set by the committee members.
\end{abstract}

Keywords: mosque; conflict; imam; committee members; religious/bureaucratic authority

A common narrative in the literature surrounding mosques is the decline of religious authority (Peter 2006; cf. Sunier 2018). ${ }^{1}$ Scholars argue that this decline is due either to the process of individualisation among the younger generations (Cesari 1998, 2003; Hervieu-Léger 1999; Roy 2005) or to the emergence of a new religious authority instead of the traditional authority of imams (Mohsen-Finan 2003) - the reference here is primarily to 'conference speakers' ${ }^{2}$ who act outside traditional institutions and whose legitimacy is often charismatic and mediatic (Frégosi 2004, p. 140). However, there has been no significant work on the process of institutional deregulation which

1 Despite the epistemological problems surrounding the concept of "religious authority," I use it in this article primarily due to its constant presence in the works of scholars who propound the narrative of decline that I intend to challenge here. On the one hand, Asad (1993) has sharply demonstrated the way in which the abstract category of "religion" is historically constructed based on the protestant idea of inner belief- making its unquestionable (and almost instinctive) usage to study Islam highly problematic. On the other hand, the concept of "authority" which is still shaped by the famous Weberian tripartite classification (traditional, charismatic and legal-rational) is mainly based on its opposition to "persuasion." As explained by Blau (1963, p. 307), "In persuasion, for example, one person permits the influence of another to influence his decisions or actions. Authority is distinguished from persuasion by the fact that people a priori suspend their own judgment and accept that of an acknowledged superior without having to be convinced that his is correct." In the case of imams, such an understanding is overly misleading: Not only the imam's opinions expressed to members of the congregation have an "ethical authority" as showed by Agrama (2010) in his study of Al-Azhar mosque in Egypt, in the sense that both muftì (scholar answering the question) and questioner "find their way together" by sharing a "responsibility rooted in reciprocal conditions of perplexity and uncertainty-perplexity of the fatwa seeker about what to do, and uncertainty of the mufti about what to say" (p. 13), but also the role of emotions, sensibilities and temporalities is central in the Muslim's reception of the imam's fatwas (legal opinion)-what can be called the "authority of the heart" based on the prophetic hadith (saying) "istafti qalbak (... ) wa in aftāka an-nās wa aft $\bar{k} k$ " (consult your heart ... even though people give you their opinion and continue to do so) (hadīth 27 in An-Nawawī's Forty Hadith (An-Nawawī 1997)).

2 For example, Frégosi (2004) studies the case of Tariq Ramadan. 
supports the claim of a fragmentation of religious authority, including the loss of imams' influence. That is, we often explain the decline of religious authority exclusively by diverse exogenous factors rather than through the analysis of the internal power dynamics within mosques. Regarding this development, although there has been important research on the role of imams in mosques in Europe (Khosrokhavar 1997; Frégosi 1998; Gaborieau and Zeghal 2004; McLoughlin 2005; Birt 2005, 2006; Hashas et al. 2018), only a few scholars have distinguished between the role of imams inside/outside the mosque and that of the mosque committee members (e.g., Jouanneau 2013; Sèze 2013; Vinding 2018) who, far from being necessarily knowledgeable in religious matters, have the task to look after the management of the mosque. More importantly, only a few studies have analysed conflicts inside mosques as part and parcel of the process of fragmentation of religious authority: Geaves (1996a), McLoughlin $(1998,2005)$ and Werbner $\left(1996\right.$; Werbner and Anwar 1991) ${ }^{3}$ tackle denominational conflicts in the UK, Van Bruinessen (2010) studies conflict between committee members and imams regarding Islamic knowledge, while Minganti (2012) analyses women's striving for "gender complementarity" through "tactical orthodoxy" in Swedish mosques.

In this paper, I suggest that rather than experiencing a decline of religious authority, mosques have become controlled by the bureaucratic authority ${ }^{4}$ of the committee members. The aim of this paper is to challenge the popular narrative of 'decline' characterised by the loss of imam's influence who was, for many years, portrayed as an important and multifunctional figure in diasporic contexts (Gaborieau and Zeghal 2004, p. 18). For this purpose, relying upon a "relational ethnography" (Desmond 2014) which gives primacy to configurations of relations and studies multiple actors and agencies engaged with one another, this paper looks at the conditions and functions of a conflict inside one mosque in an area near London. As argued by Matthew Desmond, in order to carry out a relational ethnography, we need to study cultural conflict rather than group culture. Hence, between May 2016 and September 2017, I immersed myself in the field of local Muslim leadership as a relational ethnographer who is an "in-betweener" i.e., "neither entirely inside or outside" (Milligan 2016). ${ }^{5}$ Using participant observation, informal chats and semi-structured interviews with the old and new imams, two madrassah (Islamic school) teachers, previous and current committee members and various members of the congregation, I observed "in real time fight and struggle, cooperation and compromise, misunderstanding and shared meaning-making between actors occupying different positions" (Desmond 2014, p. 556) inside the mosque. During the same period, after more than thirty years of service, the imam of this mosque resigned under the pressure of the committee who recruited a contractual imam whose sole role is to lead the five daily prayers.

In what follows, drawing on both the work of Simmel (1955) who developed a theory of social conflict that presents conflict as a form of socialisation and Coser (1956) who built on it by looking at its multiple functions, I will examine four aspects of the internal power dynamics within mosques: (a) emergence of the conflict and definition of its object, (b) the organisational structure of the mosque, (c) the actors' dynamic and interests, and (d) the functions of the conflict both in terms of division of roles inside the mosque and 'weaponisation' of rules by the committee members in order to control the

3 These studies have focused on conflicts mainly from a denominational perspective, for example: Deobandi Vs Barelvis, Shi'a Vs Sunni, etc.

4 I prefer to use 'bureaucratic authority' instead of the famously Weberian category of 'legal rational authority' primarily because of the implied coercive character of the "legal" (Schauer 2015) and its absence in the "authoritative" (Kramer and Schmidtke 2006). Hence, my contention finds roots in the oxymoron that lies behind the conceptualisation of law and authority in its relationship to coercion, which was minutely examined by Agrama (2010, p. 6) who concludes: "if law is distinguished mainly in terms of its coercive character and authority is defined as willing obedience irreducible to coercion, the concept of legal authority becomes something of a contradiction in terms."

5 I use the category "in-betweener" not only because I agree with Milligan (2016, p. 240) that "the boundaries both between insider and outsider and other identities were often messy and difficult to define" but also because it is the way I was perceived by members of congregation due to the entanglement of various racial, religious, national and linguistic factors which I cannot detail here. 
imam's role. The analysis of the conflict will help us to assess the narrative of decline and propose an alternative direction in the study of local Muslim leadership.

\section{Facets of Religious Authority}

In this mosque built in 1982 by a group of Kashmiris led by Haji Salim, ${ }^{6}$ two groups emerged based on the villages of origin: Bargil and Kardal. Both villages were impacted by the construction of the Mangla Dam in 1966 which obliged many habitants of the larger area of Mirpur District in Azad Jammu and Kashmir (AJK) to migrate to the UK. With a work permit in hand, male Bargilis and Kardalis came with the obvious intention to return. But after several years and due to various endogenous and exogenous factors, the intention started to take the form of a myth (Anwar 1979) by moving from "sojourners to citizens" (Haddad 2002). In 1971, the UK passed the Immigration Act that allowed Commonwealth citizens already in the UK to remain, while holders of British passports born overseas could settle. Family reunification means the start of a 'mourning of return' illustrated in a socio-demographic rejuvenation, community formation and the quick development of housing investment in the host country.

One of the most important symbols of this mourning is the mosque to which "British Muslims have devoted more energy and resources [... ] than perhaps to any other institution" (Gilliat-Ray 2010, p. 181). The only other place which has an equivalent symbolism of "rootedness" is the burial ground for Muslims (Ansari 2007). Hence, undoubtedly, the mosque is a place that responds to the community members' need of worship, but also a cherished space where the tradition of Barelvism or "ahl-i Sunna wa al-jama' $a^{\prime}$ " (adherents to the prophetic tradition and the community of followers) ${ }^{7}$ that people from Bargil and Kardal belong to is revived and embodied by the youth who believe in their belonging to the land where they were born (where the mosque was built by their parents) more than any other land. It is therefore a place with a deep sense of both belonging and ownership that results sometimes in conflicts that go beyond any tribal or ideological belonging. ${ }^{8}$

In this context, the imam plays an important role: he is the umbilical cord between the tradition and the host culture, between the first generation and the second one, between the text and the context. It is true that back home (in the whole South Asian region), the imam occupied a low functionary status with little capital (Lewis 1994, p. 82), but in many cases in the UK, particularly among the Barelvi community, the imam demanded considerable respect-not only because the majority of babas (elderly men) were illiterate and used to see him as an "samandar (ocean) of knowledge" (Usman, previous committee member, 71), but because he was generally appointed by a pir that the members of the community venerate and have probably bay'at (allegiance) to. This is what happened with Imam Mahboob in 1983 when he was recommended by a famous pir to the five committee members who founded the mosque. He was neither from Bargil, nor from Kardal, but he had an important religious authority. According to Ahmad (69), one of the early members of the current committee, the babas could not make any decision without his agreement. They regarded the imam, Ahmad says, as "the khalifa (vicegerent) of the pir " who is "the epitome of the prophet's characteristics; loving, kind, handsome and of generous nature" (Khan 2006, p. 23). ${ }^{9}$

6 All the names of people, groups and villages have been changed to preserve confidentiality.

7 This appellation is used by practitioners to oppose the derogatory use of Barelvi by people from other denominations (particularly Deobandis and Ahl-I Hadith) in the sense of being outside the sunna (tradition) of the prophet.

8 Previous studies refer to conflicts in mosques to point out the damaging role of "sects" or that of baradaris in which the categories of class and race are entangled. In my research, I demonstrate that conflicts can be also linked to the process of confronting tradition-based imaginaries with the bureaucratic transformation of mosques in the West.

9 This was not always the case. Drawing on his insider experience, Khan (2006, p. 24) says: "the norm for most imams from the Indian subcontinent, including the Barelvis, [was] to shout during sermons. In my view the imams generally lacked the dignity and the sophistication of the pirs. The pirs had charisma whereas most of the imams did not." However, even in this case, they were still respected if recommended by a $\bar{p} \bar{r}$. 
Often social scientists talk about the decline of imams' religious authority in Europe without defining its nature (Cesari 1998; Frégosi 2004; Mohsen-Finan 2003). In order to demonstrate the impact of individualisation which is "meant to signify primarily an Islam lived in the private sphere [ ... ] where the believer decides autonomously which elements of Islam (s)he considers to be binding or not" (Peter 2006, p. 106), these scholars tend to point out the emergence of "new leaders" (Roy 2004) as well as novel Islamic spaces created by second generation actors (Mandaville 2001, p. 124; Özyürek 2014) which lead directly or indirectly to the loss of imam's influence and the decline of religious authority. In this sense, Mohsen-Finan (2003, p. 133) explains for example the success of Tariq Ramadan among Muslims in France and the UK as "less due to the rigour and strictness of his message than to the absence of religious authorities." In other terms, "the new generation appears often reluctant towards the traditional teaching" of imams (Cesari 1998, p. 27). It is undeniable that the second and third generation has changed the Muslim-based organisational landscape not only in the UK but in various other Western countries, but to what extent does this constitute a decline of the imams' religious authority? Before considering this, it is necessary to examine what is meant by religious authority and what are its components?

Clearly in the context of Barelvism which represents $23.7 \%$ of British mosques (459 mosques) ${ }^{10}$ the religious authority of the imam is based on the embodiment of a tradition that goes back to the sunna of the prophet through various discourses-in the case of this mosque, primarily through the hanafi madhhab (legal school) and the naqshabandì tarīqa (sufi path). The imam has authority not only over the figh $\bar{\imath}$ (legal) discourse but also over the process of embodiment via the transmission of popular devotional practices such as miläd sharîf (Prophet's Birthday) and 'urs shariff (death anniversary of a saint), na't sharif (devotional poem in honour of the Prophet) and dhikr (remembrance of God) (Khan 2006). This makes Imam Mahboob the protector of a discursive and embodied tradition (Asad 1986) in a place created primarily for this purpose. His authority is based on meeting the religious needs of a particular lay audience, it represents in this sense "the aspiration, effort, and ability to shape people's belief and practice on recognizably 'religious' grounds" (Zaman 2012, p. 29).

Moreover, unlike some Barelvi imams in the UK, Imam Mahboob did not fail to defend the devotional practices from the attacks of other groups such as Hizb al-Tahrir, particularly during the 90 's. Many kakas (youngsters) who "were rejecting both assimilation into the mainstream indigenous culture and the ethnocentricity of their parents" (Geaves 1996b, p. 59) were attracted by the doctrine of the movement. Imam Mahboob's role was crucial in challenging these ideas that were regarded by the babas as part of the broader emic category of "wahhabism." This ideological clash resulted in a "fitnah" (strife) between parents and children within many families" says Faruq (39), head of an active youth foundation in the district, "a fitnah that transformed Imam Mahboob into a psychologist." He adds:

Imam Mahboob was my saviour in a difficult time. While attending his class on Bukhari Sharif from Kitābul adab mufrad, ${ }^{12}$ I used to ask him all sorts of questions and he used to listen to me contrary to the elders. I used to challenge him, but his knowledge in the four madhabs, his knowledge of the context and his charisma-bear in mind! he was one of the few Barelvi imams who were able to speak English fluently during 80s and early 90s, until recently actually. So, he was capable in many regards to intervene positively in family conflicts but also in accompanying youth intellectually, and I was one of them.

Faruq's case illustrates the importance of Imam Mahboob's capacity in "bridging social capital" (Lewis 2006, p. 273) as a way to help youth in their aspiration for coherence (Asad 1986, p. 17) within

10 http://www.muslimsinbritain.org/index.php (link accessed on 5 April 2019).

11 This use of the term fitnah here refers to the Qur'anic verse: "wa l-fitnatu ashaddu mina l-qatl" (And fitnah is worse than killing) (Qur'an 2: 191)

12 It is the seventy eighth book of Imam Bukhari's collection of sahīh (authentic hadiths-prophetic sayings). It concerns the question of perfecting Muslim manners. 
the British context ${ }^{13}$ where Pakistani Muslim adolescents have a stronger ethnic identity compared to Indians for instance (Robinson 2009). He was clearly an exception to other imams in terms of his ability to nurture a "cultural capital" to engage in civil society (Gilliat-Ray 2010, p. 163) even if it "takes time [to] accumulate" (Bourdieu 1986, p. 241). He is the one who advised Faruq to create an institution outside the mosque to offer a space for discussion and blossoming to other kakas instead of aiming to change babas.

Of course, the role of Imam Mahboob did not stop the influence of the sum of reformist 'neo-orthodox' ideas which are observable today in almost all Barelvi mosques in the UK despite the persistence of what Geaves (2009) accurately calls the "cultural binary fission" of Sufism in Britain-a metaphor borrowed from cellular biology to refer to the way in which tariqas in the UK reproduce continuously to create a duplicate of themselves which is ethnically and locally bounded. However, in the midst of the youth's "creative, empowering, stimulating, inspiring and arousing" everyday struggle (Threadgold 2018, p. 22), Imam Mahboob accompanied them in developing a post-Barelvi understanding of the tradition primarily by seeking sufi practices beyond Kashmiri circles, particularly among internationally active scholars like the Habā'ib (plural of Habīb-referring to scholars/sayyids originated from Yemen) such as Habib Ali Jafri or Habib Umar bin Hafiz, and some American or British convert scholars such as Hamza Yusuf and Abdal Hakim Murad. ${ }^{14}$ In other words, he was able to canalise the youth's "individualised" quest of truth through a form of Barelvism which can discursively embrace novel sufī practices.

Bano (2018a) proposes measuring the scholar's Islamic authority according to three components: (1) his textual knowledge of Islamic sciences and command over Arabic, (2) his moral authority i.e., "the scholar's way of life, as reflected in his adab (Islamic norms of behavior), uprightness, and conduct on material matters. [ ... ] The persona of the Prophet and his Sunnah become the model against which the scholar is judged; in the spirit of the Prophet's tradition, the scholar is expected to live by what he teaches" (p. 31), and (3) his knowledge of everyday social realities. Drawing on my fieldwork, these three dimensions represent Imam Mahboob's religious capital (Iannaccone 1990), or rather spiritual capital (Verter 2003). Regardless of the problematic use of the adjectives 'religious' and 'spiritual' that I cannot discuss here, ${ }^{15}$ Verter's conceptualisation is interesting not only because it draws on Bourdieu's notion of cultural capital in its three forms, i.e., the embodied state, the objectified state, and the institutionalised state (Bourdieu 1986, pp. 243-48), but mainly because it helps to sketch the three aspects of Imam Mahboob's religious authority. Firstly, the embodied state means that the spiritual capital is embodied in the habitus, it is not only about Imam Mahboob's position but also about his dispositions and inward/outward capacities. Secondly, the objectified state refers to the fact that Imam Mahboob holds a set of objects, texts and vestments (Bourdieu 1986, pp. 246-47) such as the 'amāma (turban) that he appropriated from his master and which can be "consumed" by disciples and members of the congregation. Finally, the institutionalised state is related to Imam Mahboob's qualifications from various renowned Islamic institutions in Pakistan and elsewhere, including al-Azhar in Egypt where he spent one year.

Drawing on this understanding of Islamic authority and spiritual capital, is it accurate to talk about a decline of religious authority in Imam Mahboob's case? What is the process taking place in mosques if it is not a decline of religious authority? What is the role of conflict in this process? What are its functions regarding the mosque's internal dynamics and what is its impact on the role of local Muslim leaders (imam and mosque committee members)? I intend to explore these questions in the following sections.

13 To know about the British youth aspiration, see Franceschelli and $\mathrm{O}^{\prime}$ Brien (2015) and Hamid (2016).

14 This move is already old now, McLoughlin (2005, p. 1063) reports that in February 2003, Shaykh Hamza Yusuf was invited to speak to almost 6000 people in Bradford. This post-tariqa sufism and the absence of pìr-murî̀d relation is also described by Geaves (2012).

15 For a thorough theoretical discussion of these concepts, see Ahmed (2016). 


\section{The Analysis of Social Conflict}

a. Emergence of the conflict and definition of its object:

According to Adnan (66), a previous chairman from the Bargil group, ${ }^{16}$ the two groups started to emerge in 1983, when the committee decided to fire Mufti Hasan while he was in Kashmir for holiday. Mufti Hasan was a member of the community who volunteered himself to lead the five daily prayers and deliver the jum'a khutbah (Friday Sermon). He was known for his forthrightness, that is, "he was never hesitant to tell some members of the committee that their commerce of alcohol is harām (illicit)," says Adnan. Hence, many worshipers including his peers in naqshabandī tarīqa stood firm against the decision to fire him, which resulted in organising the first elections in 1983. Other informants who joined the mosque during the 90 s trace the formation and the proper engagement of the two groups to their diverse responses to the new constitution drafted in 2001. They refer to the conflict arising from the process by which the management committee was to be appointed. The Kardal group defended an election mechanism while the Bargil one preferred selection. Although the latter accepted the use of elections for many years, disagreement over how to organise and nominate mosque committee members reinforced the conflict between the various protagonists.

It might be argued that the two groups were formed based on belonging to the same tariqa, or to the village of origin based on the network of baradari, ${ }^{17}$ or to the ethnicity and class that derives from the caste system, but none of these explain the current constitution of the two groups. In both groups, we find people named Raja and others named Chaudhary (names referring originally to castes), we find also people coming from Bargil/Kardal and from other villages such as Solu or Pilan. The composition of each group does not derive necessarily from the migration ties, whether interpersonal, organisational or composite (Granovetter 1973; Poros 2011).

Taking all the narratives into considerations, there is a constellation of interests and motivations behind the groups' formation. The only certainty here, is that the conflict could not emerge without what Coser (1956, p. 38) called the high frequency of conflictual occasions due to the closeness of relations, i.e., "the closer the relationship the more intense the conflict." Members of both groups were living in the same district where habitat is grouped, and where the mosque represents the centre of everyday interaction. This connection was not only centred on mosque management, but on all sorts of personal and community affairs.

\section{b. The organisational structure of the mosque:}

Originally, along with the imam, only five people used to oversee the management of the mosque after its construction in 1982. Under Imam Mahboob's guidance, these people continued to manage the mosque's logistic affairs until 1992 when they succeeded to collect the necessary amount of money to buy the next door's warehouse and extend the mosque. The project included adding additional floors reserved to women in the old building as well as the construction of a madrassah (used also as a prayer space during Fridays and other celebrations), a larger wudu (ablution) area and a minaret on the new site. As a result, the mosque's capacity has almost doubled from 220 people in 1982 to 500 in 1992. This has engendered an important shift in management: in addition to the important financial involvement of some members who expressed their interest in joining the management committee. The extension resulted in the proliferation of everyday managerial tasks that led to increase the number of committee members.

16 After the formation of the two groups in conflict, the name of the villages of origin became officially used to design the two parties taking part in mosque's internal elections. 'Bargil group' and 'Kardal group' is an emic designation that I will use in the rest of the article.

17 It derives from the Persian word baradar meaning 'brother,' and it means an extended kinship group that "perpetuates itself through the institution of arranged marriage". 
The management committee is composed currently of 25 directors who work on a voluntary basis and who are elected every two years to manage the mosque. The nomination is completed through a process of informal preselection within the two groups which intensifies kinship and the role of baradari, while the voting system is based on an open-list proportional representation (PR) which increases polarisation between the two groups. Lardeyret (1991) says "PR is dangerous" when "faced with ethnic or cultural divisions" (p. 32), it "tends to reproduce ethnic cleavages in the legislature" (p. 35). Hajji Salim (69), the current chairman describes the process by saying:

You are campaigning for your group and I am campaigning for mine. But in order to present 25 people, I and you have to go and find those people who can get more votes, family, friends, etc. It doesn't matter if they can't read the namaz, if they can't do their prayer properly, if they don't come to the mosque, more than that, if they do illicit jobs ... like selling alcohol ... they can be in the management committee! So when we come to vote, I tick 25 Bargil and you tick the 25 Kardal.

Therefore, the work of this mosque's committee is within a functional organisational structure, where we find a management committee, education committee, maintenance committee, and fundraising committee. Although the management committee is composed of nine people, the main tasks are shared mainly between the chairman and the secretary, who is also head of the education committee and spokesman of the mosque. Members of both groups acknowledge the need for a harmony between the chairman and the secretary in order to assure a satisfactory governance of the mosque, yet they all point out the "danger" when they both have full power. In this regard, the Bargil group points out also the importance of the imam's presence in the decision making as the "religious and spiritual leader" of the mosque, independently of his belonging to the same tariqa or village of other members in the committee.

c. The actors' dynamic:

Right before 2001, due to the intensification of the polarisation between the Bargil and Kardal parties, Imam Mahboob, who arrived in 1983 to replace Mufti Hassan, intervened to resolve the dispute. A new committee composed of 25 people was formed: twelve from each group and one neutral person appointed by the imam. Although the imam divested conflict situations of "non-realistic elements of aggressiveness" so as to allow the contenders to deal realistically with the divergent claims at issue (Coser 1956, p. 60), the committee dissolved ten months later, and another election took place because the imam's role itself was an object of conflict. After this first internal attempt at mediation, which failed to reach a compromise, the Bargil group (which is close to the imam) resorted to a legal mechanism for conflict resolution in 2003. One of its members sued the Kardal committee in a commercial court. The judge suggested signing an agreement between the two groups and to find an external mediator.

After a few days, both groups communicated the problem to an important religious figure in the UK and proposed him as a mediator due to his scholarly renown and authority among all Barelvis. He accepted reluctantly and appointed a new committee (eleven from each group) and asked three barristers to draft a new constitution. The first two drafts were refused because of their similarity to the 2001 constitution, and the third one was refused by the Kardal group for allegedly preparing the ground for establishing a selection process. Fawaz (56), one of the current committee members describes this third draft by saying:

The barrister said "select a panel from the community which will act as a jury. This panel that you can name 'advisory board' might include the imam as well. Then, call for applications ... for all positions except the chairman. Forget about a chairman position! During meetings, you simply propose a person to chair. Then, interview the applicants and choose the best ones. The selected team will act as the new executive committee."

Between 2006 and 2009, the conflict sharpened, and the object of conflict became clearly defined: the Bargil group defended selection as a process of nomination and the protection of Imam Mahboob's active 
role in management while the Kardal group advocated election and the permanent marginalisation of the imam as an employee. In 2010, members of the Kardal group decided to go to the court and challenge the external mediation. After one year, the judge decided that the mediation was not binding in the light of the constitution of 2001. He also ordered a secret ballot and considered anyone who participated in the election of 2001 and 2003 as a full member of the mosque.

\section{d. Functions of the conflict:}

The enrolment in "judiciary quarrels" (Coser 1956) led to three things: an intensification of the conflict, a division of roles and a weaponisation of rules. First, the boundaries between the two groups were never clear as such. Before, people who are not originally from Bargil or Kardal used to move between the two groups for various political and social reasons. The court's decision resulted in a clear separation between the two groups in terms of social and political participation. It reinforced both a form of 'ethnicisation' (Rajesh 2000) that was much more porous back home (Gandotra 2011), and a clear-cut political partisanship.

Second, the process resulted in a division of roles through several bureaucratic procedures and policies. The role of the imam now became circumscribed within the framework of the constitution and the contract of employment; in other words, the imam's daily activities were distinctly arranged by the committee. In this sense, the imam had no role in the management of the mosque anymore. He was in charge of the ritual tasks only, while the management committee were responsible for all what is perceived by them as profane that is, which "does not require a religious expertise" (Fawaz, 56). The exercise of religious and spiritual authority by the imam became controlled by the bureaucratic authority of the committee members.

Finally, the organisational policies are weaponised by a group versus the other, notably because of the centralisation of power in the hands of the chairman and the secretary. ${ }^{18}$ The imam who was close to the Bargil group was obliged to resign after more than thirty years of service under the pressure and control exercised by the chairman and secretary who were both members of the Kardal group. The imam was no longer able to exercise his role inside and outside the mosque which allows for his religious authority to flourish and his spiritual capital to be displayed. Appointments of new staff were organised in a way to distance the imam from the congregation: his courses of Arabic and Hadith were stopped because the committee recruited a new madrassah teacher who teaches in the same hall where the imam used to. Moreover, a new imam was recruited to give a second khutbah entirely in English during jum'a, which obliged Imam Mahboob to give the first khutbah only in Urdu as it is attended mainly by the elders. The fact that "many mosque committees still seem reluctant to employ such British trained imams" (Lewis 2014, p. 238) was used by this committee as an argument to justify its so-called "progressive change" (Imran, Secretary, 49). Furthermore, an attendance record has been established by the committee as a way to control the imam's presence for all five daily prayers in the mosque making his duties vis-à-vis the community both in the local area and beyond often unachievable.

Activities such as participation in interfaith dialogue initiatives, whispering the adhān (first call for prayer) and iqāma (second call for prayer) in the newborn baby's ears, counselling regarding marriages and divorces, reading Qur'an and al-Burda ${ }^{19}$ to a sick person in hospital and so forth are today extremely controlled bureaucratically. Instead of going to visit members of the community flexibly in person, the imam is obliged to stay between prayers in his office to respond to people's questions and take notes of the various requests expressed by members of the congregation which are later transferred to the secretary. His preliminarily role is henceforth to respond bureaucratically to Muslims' "everyday

18 I asked the secretary Imran about his role, he said: "I manage everything. I might delegate some tasks but I manage everything. The external actors such as the police, county council, schools, and churches will contact me if they need anything; I am the spokesperson of the mosque."

19 Famous poem "Ode of the Mantle" praising the prophet and written by Imam al-Būsīri (d. 1294). 
concerns" (Sartawi and Sammut 2012). His religious authority is still exercised, yet only within the bureaucratic framework set by the committee members.

\section{Discussion and Concluding Remarks}

So far, I have analysed the conflict in which the imam's role within the management of the mosque is the main object of conflict. To explain the conflict, I scrutinised the organisational structure of the mosque as well as the dynamic of the groups and their leaders. During fourteen months of intensive fieldwork, I was able to observe that his religious authority and spiritual capital remained intact. His decision to resign in the tenth month of my fieldwork was even supported, not to say proposed, by many members of the congregation from both groups, Kardal and Bargil, who were ready to help him create another institution. The day after his departure, Imam Mahboob had still to officiate a nikāh (marriage) in the groom's house, lead a janāza (funeral) and attend a khatam (in honour of a deceased relative). Two months after he left the mosque, his daily schedule was still full, babas and kakas were still coming to his house asking all sorts of questions. Undoubtedly, he is still Imam Mahboob.

However, it is important to analyse what happened in the last ten to fifteen years inside the mosque ${ }^{20}$ it is not a decline of religious authority but rather the rise of bureaucratic authority. This is not to argue that conflicts between imams and committee members were inexistent before: Werbner (1996) has well described the tripartite caste-driven polarisation both in South Asian and British mosques between "saints, scholars and lay preachers." It is rather to point out the move from inter and intra-denominational conflicts analysed by scholars such as Ron Geaves, Sean McLoughlin and Pnina Werbner to bureaucratic conflicts that transcend the denomination and ethnicity of the congregation members. Not only is a displacement of power witnessed, but also a control of religious authority through bureaucratic mechanisms.

A strong argument in the narrative of decline is that 'technological advancement' has reinforced individualisation (particularly among youth) and therefore led to the decline of religious authority. Inspired by the work of Francis Robinson on the impact of the printing press in the Islamic world as "attacking the very heart of Islamic systems for the transmission of knowledge" (Robinson 1993, p. 134), Eickelman and Piscatori (2004) are at the front stage of this position. They talk about the process of fracturing of Islamic authority. As I said earlier, it is impossible to deny the influence of social media in the so-called Islamic revivalism in the West and elsewhere; however as explained by Bano (2018a, pp. 11-22): “The technological advancements of the last three decades have indeed, therefore, led to increased competition among Islamic authorities, but increased literacy and access to higher education have at the same time re-centered traditional Islamic scholarly authority, instead of eroding it." In other terms, technological advancement has also rendered the institutionalised state of religious authority central. This can be demonstrated in some of the post-Barelvi actions such as taking part in spiritual trips (e.g., Rihla program and al-Ghazālī retreat) ${ }^{21}$ with scholars ${ }^{22}$ to various parts of the world, actions in which imams and madrassah teachers take an important role as well. Also, Imam

20 Which coincides with the same period when the main academic works arguing for the decline of mosques' role and imams' religious authority were published.

21 Drawing heavily on the work and life-legacy of al-Ghazāli (d. 1111), the Rihla program is an annual retreat initiated by Hamza Yusuf under the Deen Intensive Foundation fifteen years ago, it took place in various parts of the world (Morocco, Turkey, Malaysia, etc). The al-Ghazālī retreat is organised every year in Spain and it is led by Tim Winter (Abdal Hakim Murad) and Umar Faruq Abd-Allah. Both retreats attract participants from various schools of thought and from both Western and Muslim majority countries as observed by Bano (2018b, pp. 13-15).

22 Bano (2018a, p. 11) recalls in this regard one of her interviewees' position regarding his participation in al-Ghazālī retreat: "Islam has a rich scholarly tradition in all fields be it fiqh, theology or philosophy. In fact, Islamic theology if properly studied is intellectually very powerful. Yet, to acquire that depth of understanding, we need to go back to work of great Islamic legal scholars, theologians, philosophers, and mystics and it is simply not possible to study those dense texts on your own. You need to be guided by a teacher and ideally a teacher who has very sound proficiency of Arabic grammar in addition to knowing that specific text. [ ... ] That is why I like to attend such retreats. I don't have time to pursue study of Islam full time, but participation in these short retreats acts as a good reminder that there is much intellectual depth to Islamic scholarly tradition." 
Mahboob is today using social media to reach his congregation which is increasingly literate-his Facebook page is constantly consulted by members of the congregation. In this sense, the argument that the role of mosques is declining because of technological advancement is increasingly caducous.

In this article, rather than focusing on exogenous factors such as individualisation either as a critical juncture i.e., generational change (Cesari 1998) or as part of a reformist discourse that is having an important impact on the role of imams and mosques (Amir-Moazami and Salvatore 2003), my objective is to point out the internal organisational transformation and its impact -as part of the historical condition of 'bureaucratisation'- on the possibility of an imam to maintain or to lose his religious authority. The point is not to claim that the mosque is a space of hierocracy or an essential site of struggle over the "principles of hierarchization" (Bourdieu 1993), but rather to allude to the internal transformation taking place under the modern nation state apparatus in the West. As Peter (2006, p. 112) remarks "one misses an exploration of how intra-Muslim relations influence the shaping of structures of religious authority." In this article, I add to this important point that one misses the historical conditions that shape intra-Muslim relations. Hence, to go back to the argument of individualisation, I agree with Peter who asserts that "any study of individualization needs to be based on a certain understanding of institutionalized Islam" (Peter 2006, p. 113).

My concern is not whether the individualisation of Islam and the fragmentation of religious authority will lead to the liberalisation of Islam (Mandaville 2001; cf. Roy 2005). Such affirmation has shown to be precipitous not only because of the fallacy of the secularisation thesis that puts 'Western Islam' in a trajectory of progress towards liberalism, ${ }^{23}$ but also because recent studies have shown the attachment of Muslim youth to imams and 'ulamas in various religious institutions in France (Van Praet 2019), Belgium (Groeninck 2017), and so forth. Rather I am interested in demonstrating the dynamic created by bureaucratisation both as a discourse shaped by secularism and neoliberalism and a material condition that transforms the role of local Muslim leaders (imams and mosque committee members).

Scholars need not only focus on the role of committee members as part and parcel of the field of local Muslim leadership -instead of focusing on imams only-, but also and more crucially, to study the role of local Muslim leaders as an "object of observation" rather than an "object of study" shaped by political and mediatic doxa. Differentiating the object of observation (local Muslim leaders) and the object of study (in this case, bureaucratisation of mosques) would help "to attend to wider patterns of power relations-that is, the historical processes and global flows that produce our objects of observation in the first place" (Fernando 2014, p. 24). In the West, the field of local Muslim leadership is one of the interesting "shadows" (Asad 2003, p. 16) and "lenses" through which one can understand the dynamic of the secular today. Such a shift is crucial irrespective of the denomination, nationality or ethnicity of the congregation. It must occur beyond any "substantialist perspective," that is, a perspective that focuses on "internally homogeneous and externally distinctive and bounded objects" (Desmond 2014, p. 551). While I make this call, surrounded by youngsters and other members of the congregation, Imam Mahboob is creating his own institution based on his religious authority which did not decline. However, in an "age of total bureaucratisation" (Graeber 2015, p. 17) which includes the bureaucratisation of mosques as I showed in this paper, it is only a matter of time before he exercises in turn a bureaucratic authority.

Funding: This research was generously funded by the Cambridge Trust, the Woolf Institute, the IJURR Foundation and the Leche Trust.

Acknowledgments: I would like to thank anyone who gave up his precious time to be part of this study. Thanks also to Sami Everett, Nadia Fadil and my anonymous reviewers for their comments on various versions of this article. Thanks to the organisers and attendants of the "Conference on Leadership, Authority and Representation in the Muslim Community" (particularly Sophie Gilliat-Ray and Riyaz Timol) at Cardiff University (21 January 2019),

23 For further discussion, see Massad (2015). 
and the panel "Research on Islam and beyond around the world" at the 117th Annual Meeting of the American Anthropological Association (AAA) in San Jose (16 November 2018) for their helpful feedback.

Conflicts of Interest: The authors declare no conflict of interest.

\section{References}

Agrama, Hussein Ali. 2010. Ethics, tradition, authority: Toward an anthropology of the fatwa. American Ethnologist 37: 2-18. [CrossRef]

Ahmed, Shahab. 2016. What Is Islam? The Importance of Being Islamic. Princeton and Oxford: Princeton University Press. Amir-Moazami, Schirin, and Armando Salvatore. 2003. Gender, generation, and the reform of tradition: From Muslim majority societies to Western Europe. In Muslim Networks and Transnational Communities in and across Europe. Edited by Stefano Allievi and Jorgen Nielsen. Leiden: Brill, pp. 52-77.

An-Nawawī, Yahya. 1997. An-Nawawī's Forty Hadith. Translated by Ezzeddin Ibrahim, and Denys Johnson-Davies (Abdul Wadoud). Cambridge: Islamic Texts Society.

Ansari, Humayun. 2007. Burying the dead': Making Muslim space in Britain. Historical Research 80: 545-66. [CrossRef]

Anwar, Muhammad. 1979. The Myth of Return: Pakistanis in Britain. London: Heinemann.

Asad, Talal. 1986. The Idea of an Anthropology of Islam. Qui Parle 17: 1-30. [CrossRef]

Asad, Talal. 1993. Genealogies of Religion: Discipline and Reasons of Power in Christianity and Islam. London: Johns Hopkins University Press.

Asad, Talal. 2003. Formations of the Secular: Christianity, Islam, Modernity. Stanford: Stanford University Press.

Bano, Masooda. 2018a. Modern Islamic Authority and Social Change (Volume I). Edinburgh: Edinburgh University Press.

Bano, Masooda. 2018b. Modern Islamic Authority and Social Change (Volume II). Edinburgh: Edinburgh University Press.

Birt, Jonathan. 2005. Locating the British Imam: The Deobandi Ulama between Contested Authority and Public Policy Post- 9/11. In European Muslims and the Secular State. Edited by Jocelyne Cesari and Sean McLoughlin. Aldershot: Ashgate Publishing Limited, pp. 183-96.

Birt, Yahya. 2006. Good Imam, Bad Imam: Civic Religion and National Integration in Britain post-9/11. The Muslim World 96: 687-705. [CrossRef]

Blau, Peter M. 1963. Critical Remarks on Weber's Theory of Authority. The American Political Science Review 57: 305-16. [CrossRef]

Bourdieu, Pierre. 1986. The Forms of Capital. In Handbook of Theory and Research for the Sociology of Education. Edited by John G. Richardson. New York: Greenwood Press, pp. 241-58.

Bourdieu, Pierre. 1993. The Field of Cultural Production: Essays on Art and Literature. Edited and Introduced by Randal Johnson. Cambridge: Polity.

Cesari, Jocelyne. 1998. Musulmans et Républicains: les Jeunes, l'Islam et la France. Brussels: Editions Complexe.

Cesari, Jocelyne. 2003. Islam, Citizenship and European Integration. London: Routledge.

Coser, Lewis A. 1956. The Functions of Social Conflict. London: Routledge.

Desmond, Matthew. 2014. Relational Ethnography. Theory and Society 43: 547-79. [CrossRef]

Eickelman, Dale F., and James Piscatori. 2004. Muslim Politics. Princeton: Princeton University Press.

Fernando, Mayanthi. 2014. The Republic Unsettled: Muslim French and the Contradictions of Secularism. Durham: Duke University Press.

Franceschelli, Michela, and Margaret O'Brien. 2015. Being modern and modest': South Asian young British Muslims negotiating multiple influences on their identity. Ethnicities 15: 696-714. [CrossRef]

Frégosi, Frank, ed. 1998. La Formation des Cadres Religieux Musulmans en France: Approches Socio-Juridiques. Paris: L'Harmattan.

Frégosi, Frank. 2004. L'imam, le conférencier et le jurisconsulte: Retour sur trois figures contemporaines du champ religieux islamiques en France. Archive de Sciences Sociales des Religions 125: 31-46. [CrossRef]

Gaborieau, Marc, and Malika Zeghal. 2004. Autorités religieuses en Islam. Archive de Sciences Sociales des Religions 125: 5-21. [CrossRef]

Gandotra, Hema. 2011. Migration and marginality: a sociological insight of Kashmiri Pandits. Madhya Pradesh Journal of Social Sciences 16: 11-17.

Geaves, Ron. 1996a. Cult, charisma, community: the arrival of Sufi Pirs and their impact on Muslims in Britain. Journal of Muslim Minority Affairs 16: 169-92. [CrossRef] 
Geaves, Ron. 1996b. Sectarian Influences Within Islam in Britain with Reference to the Concepts of 'Ummah' and 'Community'. Leeds: Community Religions Project.

Geaves, Ron. 2009. A Case of Cultural Binary Fission or Transglobal Sufism? The Transmigration of Sufism to Britain. In Global Networking and Locality: Sufis in Western Society. Edited by Ron Geaves, Markus Dressler and Gritt Klinkhammer. London: Routledge, pp. 97-112.

Geaves, Ron. 2012. The Transformation and Development of South Asian Sufis in Britain. In South Asian Sufis: Devotion, Deviation and Destiny. Edited by Clinton Bennett and Charles Ramsey. London: Continuum, pp. 181-96.

Gilliat-Ray, Sophie. 2010. Muslims in Britain. Cambridge: Cambridge University Press.

Graeber, David. 2015. The Utopia of Rules: On Technology, Stupidity and the Secret Joys of Bureaucracy. Brooklyn: Melville House.

Granovetter, Mark S. 1973. The Strength of Weak Ties. The American Journal of Sociology 78: 1360-80. [CrossRef]

Groeninck, Mieke. 2017. Politics of 'ilm: Islamic religious knowledge transmission among female Maghrebian Muslims in the region of Brussels. Ph.D. dissertation, Katholieke Universiteit Leuven, Leuven, Belgium.

Haddad, Yvonne. 2002. Muslims in the West from Sojourners to Citizens. Oxford: Oxford University Press.

Hamid, Sadek. 2016. Young, Muslim and British: Between Rhetoric and Realities. London: Routledge.

Hashas, Mohammed, Jan Jaap de Ruiter, and Niels Valdemar Vinding. 2018. Imams in Western Europe: Developments, Transformations and Institutional Challenges. Amsterdam: Amsterdam University Press.

Hervieu-Léger, Danièle. 1999. Le Pèlerin et le Converti. La Religion En Mouvement. Paris: Flammarion.

Iannaccone, Laurence R. 1990. Religious Practice: A Human Capital Approach. Journal for the Scientific Study of Religion 29: 297-314. [CrossRef]

Jouanneau, Solenne. 2013. Les Imams en France: Une Autorité Religieuse sous Contrôle. Marseille: Agone.

Khan, Muzamil. 2006. Devotional Islam in Kashmir and British Diaspora. Ph.D. dissertation, University of Liverpool, Liverpool, UK.

Khosrokhavar, Farhad. 1997. L'Islam des Jeunes. Paris: Flammarion.

Kramer, Gudrun, and Sabine Schmidtke. 2006. Speaking for Islam: Religious Authorities in Muslim Societies. Leiden: Brill.

Lardeyret, Guy. 1991. The problem with PR. Journal of Democracy 2: 30-35. [CrossRef]

Lewis, Philip. 1994. Being Muslim and Being British: The Dynamics of Islamic Reconstruction in Bradford. In Desh Pardesh: The South Asian Presence in Britain. Edited by Roger Ballard and Marcus Banks. London: Hurst, pp. 58-87.

Lewis, Philip. 2006. Mosques, 'Ulama' and Sufis: Providers of Bridging Social Capital for British Pakistanis? Contemporary South Asia 15: 273-87. [CrossRef]

Lewis, Philip. 2014. Imams in Britain: Agents of De-Radicalisation. In Islamic Movements of Europe. Edited by Frank Peter and Rafael Ortega. London and New York: I.B. Tauris, pp. 237-40.

Mandaville, Peter. 2001. Transnational Muslim Politics: Reimagining the Umma. London: Routledge.

Massad, Joseph Andoni. 2015. Islam in Liberalism. Chicago and London: University of Chicago Press.

McLoughlin, Sean. 1998. The Mosque-Centre, Community-Mosque: Multi-functions, Funding and Reconstruction of Islam in Bradford. The Scottish Journal of Religious Studies 19: 211-27.

McLoughlin, Sean. 2005. Mosques and the Public Space: Conflict and Cooperation in Bradford. Journal of Ethnic and Migration Studies 31: 1045-66. [CrossRef]

Milligan, Lizz. 2016. Insider-outsider-inbetweener? Researcher positioning, participative methods and crosscultural educational research. Compare: A Journal of Comparative and International Education 46: 235-50. [CrossRef]

Minganti, Pia K. 2012. Challenging from Within: Youth Associations and Female Leadership in Swedish Mosques. In Women, Leadership, and Mosques. Edited by Masooda Bano and Hilary Kalmbach. Leiden: Brill, pp. 371-92.

Mohsen-Finan, Khadija. 2003. La mise en avant d'une 'citoyennete' croyante': Le cas de Tariq Ramadan. In De la Citoyenneté Locale. Edited by Rémy Leveau, Khadija Mohsen-Finan and Catherine Wihtol de Wenden. Paris: Institut Français des Relations Internationales, pp. 87-96.

Özyürek, Esra. 2014. Being German, Becoming Muslim: Race, Religion, and Conversion in the New Europe. Princeton: Princeton University Press.

Peter, Frank. 2006. Individualization and religious authority in western European Islam. Islam and Christian-Muslim Relations 17: 105-18. [CrossRef] 
Poros, Maritsa V. 2011. Modern migrations: Gujarati Indian Networks in New York and London. Stanford: Stanford University Press.

Rajesh, Gill. 2000. “Cities and Ethnicity: A Case of De-ethnicization or Re-ethnicization”. Sociological Bulletin 49: 211-28.

Robinson, Francis. 1993. Technology and Religious Change: Islam and the Impact of Print. Modern Asian Studies 27: 229-51. [CrossRef]

Robinson, Francis. 2009. Crisis of Authority: Crisis of Islam? Journal of the Royal Asiatic Society 19: 339-54. [CrossRef]

Roy, Olivier. 2004. Globalised Islam: The Search for a New Ummah. London: Hurst \& Company.

Roy, Olivier. 2005. La Lä̈cité Face à l'Islam. Paris: Editions Stock.

Sartawi, Mohammed, and Gordon Sammut. 2012. Negotiating British Muslim identity: Everyday concerns of practicing Muslims in London. Culture and Psychology 18: 559-76. [CrossRef]

Schauer, Frederick. 2015. The Force of Law. Cambridge: Harvard University Press.

Sèze, Romain. 2013. Etre Imam en France. Paris: Cerf.

Simmel, Georg. 1955. Conflict and the Web of Group-Affiliations. New York: The Free Press.

Sunier, Thijl. 2018. The making of Islamic authority in Europe. In Imams in Western Europe: Developments, Transformations and Institutional Challenges. Edited by Mohammed Hashas, Jan Jaap de Ruiter and Niels Valdemar Vinding. Amsterdam: Amsterdam University Press, pp. 51-68.

Threadgold, Steven. 2018. Youth, Class and Everyday Struggles. Abingdon: Routledge.

Van Bruinessen, Martin. 2010. Producing Islamic Knowledge in Western Europe: Discipline, Authority, and Personal Quest. In Producing Islamic Knowledge: Transmission and Dissemination in Western Europe. Edited by Martin van Bruinessen and Stefano Allievi. Abingdon: Routledge, pp. 1-27.

Van Praet, Younes. 2019. Socio-Anthropologie De L'enseignement De L'islam Dans L'agglomération Rouennaise: Rapports De Genre Et Évolutions Des Légitimités. Ph.D. dissertation, Rouen Université de Rouen, Mont-Saint-Aignan, France.

Verter, Bradford. 2003. Spiritual Capital. Theorizing Religion with Bourdieu against Bourdieu. Sociological Theory 21: 150-74. [CrossRef]

Vinding, Niels Valdemar. 2018. The making of Islamic authority in Europe. In Imams in Western Europe: Developments, Transformations and Institutional Challenges. Edited by Mohammed Hashas, Jan Jaap de Ruiter and Niels Valdemar Vinding. Amsterdam: Amsterdam University Press, pp. 231-54.

Werbner, Pnina. 1996. The making of Muslim dissent: hybridized discourses, lay preachers and radical rhetoric among British Pakistanis. American Ethnologist 23: 102-22. [CrossRef]

Werbner, Pnina, and Mohammad Anwar. 1991. Black and Ethnic Leaderships in Britain: The Cultural Dimensions of Political Action. London: Routledge.

Zaman, Muhammad Qasim. 2012. Modern Islamic Thought In A Radical Age: Religious Authority And Internal Criticism. Cambridge and New York: Cambridge University Press.

(C) 2019 by the author. Licensee MDPI, Basel, Switzerland. This article is an open access article distributed under the terms and conditions of the Creative Commons Attribution (CC BY) license (http://creativecommons.org/licenses/by/4.0/). 